\title{
Migrasi simbolik wacana kuasa tubuh: menguak wacana tubuh dalam Ode untuk Leopold Von Sacher-Masoch karya Dinar Rahayu
}

\author{
Simbolic migration of female body possession discourse: uncovering body \\ discourse in Ode for Leopold Von Sacher-Masoch by Dinar Rahayu
}

\author{
Ida Nurul Chasanah \\ Fakultas Ilmu Budaya, Universitas Airlangga. Jalan Airlangga 4-6 Surabaya 60286, \\ Indonesia \\ E-mail: ida_adek69@yahoo.com
}

\begin{abstract}
The presence of Indonesian women writers with the dominant discourse of the power of body, presenting the pros and cons that would not go over. Female body is the language of women that can be poured through the writing of literary works. Helene Cixous brought the spirit of "writing the body" to motivate women authors to express himself through written discourse, which so far has been dominated by men. Cixous spirit is also promoted by Dinar Rahayu appear in the novel Ode untuk Leopold Von Sacher-Masoch. Dinar Rahayu voicing complexity of urban women's voices in this novel through several migration symbolic of the power of the female body. Migration is enriched by the presence of symbolic power in a sound body of Greek and Scandinavian mythology and Leopold voices in his work Venus in Furs. Through in-depth reading on the symbolic migration brought to the Ode untuk Leopold Von Sacher-Masoch through the voices of the characters and the particularities of naration techniques can be seen that this novel (as well as other sexist novels) is not merely a commodity that exploit sexuality pornography but rather an attempt to author urban female voices will be the "body power". This study uses content analysis method that begins with the reading of literature, heuristic and hermeneutic, and take advantage of intertextuality approach.
\end{abstract}

Keywords: symbolic migration, body power, women authors urban, and Ode untuk Leopold Von Sacher-Masoch

\begin{abstract}
Abstrak
Kehadiran penulis perempuan Indonesia dengan wacana dominan kekuatan tubuh, menghadirkan pro dan kontra yang tidak kunjung usai. Tubuh perempuan adalah bahasa wanita yang dapat dituangkan melalui penulisan karya sastra. Helene Cixous membawa semangat "menulis tubuh" adalah untuk memotivasi perempuan penulis mengekspresikan dirinya melalui wacana tertulis, yang sejauh ini didominasi oleh laki-laki. Semangat Cixous juga dipromosikan oleh Dinar Rahayu muncul dalam novel Ode untuk review Leopold Von Sacher-Masoch. Dinar Rahayu menyuarakan kompleksitas suara perempuan urban di novel ini melalui beberapa migrasi simbolis kekuatan tubuh perempuan. Migrasi diperkaya dengan kehadiran kekuatan simbolik dalam tubuh yang sehat dari mitologi Yunani dan Skandinavia dan suara Leopold di Venus karyanya Dalam bulu. Melalui mendalam membaca tentang migrasi simbolik dibawa ke Ode untuk review Leopold Von Sacher-Masoch melalui suara karakter dan kekhasan teknik narasi dapat dilihat bahwa novel ini (serta novel seksis lainnya) tidak hanya komoditas yang mengeksploitasi seksualitas pornografi melainkan upaya untuk penulis suara perempuan perkotaan akan menjadi "kekuatan tubuh". Penelitian ini menggunakan metode content analysis yang diawali dengan pembacaan sastra, heuristik dan hermeneutik, dan memanfaatkan pendekatan intertekstualitas.
\end{abstract}

Kata kunci: simbolis migrasi, kekuatan tubuh, wanita penulis perkotaan, dan Ode untuk review Leopold Von Sacher-Masoch

\section{Pendahuluan}

Dalam setiap masyarakat, tubuh senantiasa menjadi objek kuasa. Tubuh dimanipulasi, dilatih, dikoreksi menjadi patuh, bertanggungjawab, menjadi terampil dan meningkat kekuatannya. Tubuh senantiasa menjadi sasaran 'kuasa', baik dalam arti 'anatomi metafisik' yakni seperti yang dibuat oleh para dokter dan filsuf, maupun dalam arti 'teknik politis' yang mau mengatur, mengontrol atau mengoreksi segala aktivitas tubuh. Kuasa, dari masa yang satu ke masa yang lain, selalu menyentuh tubuh, hanya cara, ukuran dan sasaran kontrolnya saja yang senantiasa berubah-ubah. Foucault (1981) 
menyebut usahanya sebagai 'studi perubahan model strategi menghukum' dengan berpangkal pada penelusuran "teknologi politis terhadap tubuh". Teknologi politis terhadap tubuh akhirnya sampai pada "perhatian" terhadap tubuh yang tadinya harus disiksa sampai pada tubuh yang harus dilatih agar disiplin. Bentuk ini merupakan "penghargaan" terhadap tubuh.

Tubuh perempuan sepanjang masa merupakan perdebatan-perdebatan yang amat kontroversial. Perdebatan-perdebatan tersebut muncul dalam berbagai bidang. Perdebatan tubuh dapat ditemui dan diterjemahkan secara biologis, seksual, ekonomi, agama, politik, budaya maupun sastra. Bentuk subordinasi tubuh perempuan yang tertanan kuat di bawah bayang-bayang ideologi patriakal, ternyata juga merasuk dalam karya sastra. Dalam kaitannya dengan persoalan kuasa tubuh, baik dalam sastra daerah, sastra Indonesia, maupun sastra dunia, pembicaraan seputar wacana tubuh itu merupakan suatu ketelanjuran. Gatoloco, Centini, Pengakuan Pariyem, Madame Bovary, dan Lady Chatterley's Lover adalah sejumlah contoh betapa persoalan kuasa tubuh sudah merambah karya sastra sejak lama.

Migrasi kebudayaan melalui urbanisasi yang berlangsung secara masif pada abad ke-21 ini tidak hanya menandai mobilitas fisik tetapi juga sikap, gaya hidup dan pemikiran. Kota, sebagai arus pusat masyarakat urban, menciptakan kebudayaan yang memiliki nuansa yang lebih terbuka dan cair; meluruhkan sekat-sekat kebudayaan yang dianggap "tinggi" dan "rendah" atau "kanon" dan "pop". Seiring kemajuan teknologi multimedia, sastra Indonesia kontemporer- sebagai salah satu produk budaya urban menjadi bagian dari "gaya hidup" masyarakat urban perkotaan yang tidak lagi bersifat beku, statis, dan kedap dari dinamika perkembangan zaman. Hal ini dapat dilihat dari kompleksitas suara-suara perempuan pengarang urban pada awal tahun 2000 melalui produksi karya mereka yang mengedepankan wacana relasi kuasa tubuh.

Michel Foucault (1981) mengatakan bahwa kekuasaan ada di mana-mana, di satu sisi banyak yang mengatakann bahwa subjek tidak diberi tempat, namun di sisi lain, mungkin ada persoalan pemosisian, yakni bahwa subjek berada di mana-mana. Dalam konteks ini, pengarang tidak lagi mati, masyarakat tidak lagi tanpa subjek. Jika persoalan kekuasaan dilihat dari sisi pandang Foucault, maka kekuasaan bukanlah kekuasaan laki-laki yang secara sistemik menjadi satu-satunya kekuasaan terpusat dengan dominasi dan hegemoninya.

Pembicaraan mengenai relasi kuasa tubuh dalam karya sastra, khususnya karya para perempuan pengarang Urban di Indonesia, menunjukkan adanya pergerakan subjek yang sangat sinergis dan dinamis. Subjek-subjek tersebut tidak bersifat homogen tetapi heterogen yang mengangkat fenomena hubungan gender, kelas, etnisitas dan agama. Subjek-subjek yang dimunculkan bukanlah subjek yang netral, tetapi subjek yang berposisi. Pemosisian subjek adalah sebagai usaha untuk mengaktualisasikan diri dalam masyarakat yang kompleks dan dinamis serta multikultural, seperti di Indonesia. Pemosisian ini juga mengimplikasikan adanya perubahan wacana sosial, poltik, dan kultural yang memungkinkan subjek-subjek tersebut memerankan fungsinya sebagai "benar-benar subjek".

Urban bukanlah kenyataan yang terbentuk secara kebetulan, ia adalah bagian dari apa yang kita kerjakan di masa silam, yang di dalamnya termasuk berbagai kebijakan politik yang tidak adil, konsep dualisme kota-desa, dan kini terhubung dengan pemiskinan masyarakat pedesaan. Sejarah itu, pada ujungnya, melahirkan kenyataan urban yang tidak terlepas dengan kenyataan kemiskinan dan pemiskinan, karena kelahirannya adalah sesuatu yang dikondisikan. Kandungan sastra tentu tak lepas dari ragam persoalan kehidupan manusia dengan segala tetek-bengeknya. Semua terpapar dengan filosofi dan citraannya. Kekayaan pengalaman referensial dan faktual yang dimiliki pengarang dapat mewarnai karya dengan ketajaman pena dan kedalaman makna yang dikandungnya.

Suara-suara perempuan pengarang urban muncul secara serentak, setelah kehadiran Saman (1998) dan Larung (2001) karya Ayu Utami sehingga sempat memunculkan beberapa sebutan, seperti "Sastrawangi", "sastra selangkangan", "sastra syahwat", "sastra perkelaminan", "sastra seksis" dan berbagai sebutan sejenis yang berkonotasi negatif. 
Berkembangnya permasalahan ini berawal dari Helene Cixous, feminis Perancis, yang memilih sastra sebagai media untuk mengubah wacana seksualitas perempuan dari maskulin menjadi feminin. Cixous (1981:280) mengemukakan bahwa tubuh atau kenikmatan seksual perempuan dapat dituangkan melalui penulisan atau sastra. Menurutnya menulis adalah media yang dapat mengungkap wacana tubuh perempuan yanng selama ini tersita oleh dominasi laki-laki. Pernyataan Cixous tersebut menyiratkan bahwa tubuh perempuan sangat erat kaitannya dengan seksualitasnya dan cara bagaimana tubuh dan seksualitas itu dipandang dalam konteks budaya laki-laki. Bagi Cixous dan Irigaray, tubuh perempuan adalah bahasa perempuan. L-ecriture Feminine- yang secara kasar dapat dimaknai sebagai "menulis tubuh" adalah bagian dari usaha untuk mencari bahasa baru yang tidak menempatkan seksualitas perempuan semata-mata sebagai objek seksualitas laki-laki melainkan sebagai bentuk proses pembentukan subjektivitas perempuan.

Elaine Showalter menulis dalam esainya "Feminist Criticsm in the Wilderness" bahwa penulisan perempuan yang sungguh-sungguh berempati terhadap perempuan hanyalah dapat dilakukan oleh perempuan karena adanya pengalaman spesifik perempuan yang tidak dialami oleh laki-laki. Dengan demikian, menurut Showalter, "teks perempuan" atau "tentang perempuan" juga hanya dapat dilakukan secara sungguh-sungguh oleh perempuan (Prabasmoro 2006:198).

Dalam khazanah kesusastraan Indonesia, perempuan pengarang sudah terlibat dalam sastra Indonesia sejak sebelum perang, seperti Selasih, Hamidah, Adlin Affandi, dan Sa'adah Alim. Kuantitas perempuan pengarang semakin meningkat setelah perang kemerdekaan usai dengan munculnya $S$. Rukiah, Nursjamsu, Walujati, Ida Nasution, Maria Amin, Suwarsih Djojopuspito, N.H.Dini, Titi Said, S.Tjahjaningsih, Sugiarti Siswadi, Ernisiwati Hutomo, Titis Basino dan Enny Sumargo (Prihatmi 1986:9). Pada tahun 1970-an, majalah wanita seperti Dewi, Femina, Gadis, Kartini, dan Sarinah mengalami pertumbuhan yang cukup signifikan. Majalah-majalah tersebut menyediakan ruang yang cukup besar bagi fiksi. Sejumlah nama perempuan pengarang muncul, seperti Marga T, La Rose, Yatti Maryati Wiharja, Maria A. Satjono, Noerna Sidharta, Aryanti, Ike Supomo, Titik Vifa, Mira W, Titie Said, Susilowati Edison dan Mariane Katoppo, yang menjadi fenomena mengejutkan dalam dunia sastra Indonesia, karena sebelumnya tidak pernah terjadi booming penulis perempuan seperti itu (Sumardjo 1982:57). Selain melalui majalah-majalah wanita, karya-karya perempuan pengarang juga hadir melalui surat kabar, seperti Kompas dan Surabaya Post. Pada masa ini mulai berkembang tulisan-tulisan populer yang sebelumnya termarjinalkan. Fenomena ini kemudian berulang di masa berikutnya (masa dekade tahun 2000-an, setelah munculnya Saman karya Ayu Utami).

Kehadiran Saman karya Ayu Utami yang sempat memunculkan pro-kontra ini seolah merupakan tonggak kebangkitan perempuan pengarang, sebab sederetan nama perempuan pengarang pun hadir dengan mengusung wacana yang sama, mempertanyakan kembali konstruksi ideologi patriarki, dalam karya-karya mereka, seolah-olah hendak membuat "isme" baru. Beberapa perempuan pengarang yang mengusung semangat yang sama tersebut di antaranya, Dewi Lestari, Fira Basuki, Herlinatiens, Nova Riyanti Yusuf, Djenar Maesa Ayu, Clara Ng, Dinar Rahayu dan masih banyak sederetan nama perempuan pengarang yang menghasilkan karya dengan wacana serupa, menuliskan tubuhnya sendiri.

Maraknya penulisan dan perayaan tubuh perempuan oleh para perempuan pengarang Indonesia mutakhir melahirkan beberapa tanggapan yang di antaranya menggunakan moral sebagai salah satu tolok ukur penilaian kritisnya. Hal ini selaras dengan pendapat Susan Sontag (1969) yang menyatakan keprihatinannya karena pornografi dan seks dalam sastra dianggap sebagai fenomena sosial psikologis dan masalah moral, bukan sebagai salah satu perkembangan imajinasi dan kreativitas literer. Baginya, karya sastra bertema seksualitas, betapapun eksplisitnya, berbeda dengan pornografi yang menggambarkan seks sebatas interaksi organ genital manusia. Karya-karya bertema seksualitas memiliki tujuan yang lebih kaya daripada sekedar deskripsi peristiwa hubungan seks dan perangsangan libido. Rangkaian peristiwa seksual dalam sebuah teks merupakan urutan kejadian dan pengalaman yang menandai awal, tengah, dan akhir sebuah cerita yang masing-masing memiliki kekhasan tersendiri dalam membentuk narasi karyanya. 
Ode untuk Leopold von Sacher-Masoch karya Dinar Rahayu merupakan salah satu dari sekian banyak novel karya perempuan pengarang Indonesia mutakhir yang membicarakan tentang kuasa tubuh. Novel ini menyuarakan kompleksitas suara perempuan pengarang urban melalui beberapa migrasi simbolik atas penguasaan akan tubuh. Kuasa tubuh yang dihadirkan mulai dari penyiksaan atas tubuh sampai penghargaan atas tubuh yang dikemas dengan sudut pandang mitologi Yunani, Skandinavia sampai pendapat-pendapat Leopold akan sadomasokisme. Semua hal tersebut, termasuk transeksual dan sadomasokisme yang menjadi ide sentral novel ini dinarasikan secara sederhana dan wajar, di tengah masyarakat yang masih menganggap penyampaian tersebut sebagai sesuatu yang kurang sopan bahkan tak bermoral sehingga sebagian kritikus menganggap karya ini sekedar mengeksploitasi seksualitas belaka. Tulisan ini akan mengungkap dan mematahkan anggapananggapan tersebut serta menyajikan beberapa kreatifitas pengarang dalam pengucapan literernya yang memanfaatkan "ruh" teks dan konteks lain.

Berdasarkan uraian di atas, maka tulisan ini akan memaparkan beberapa temuan akan migrasi simbolik yang ditemukan dalam teks sebagai bentuk kreativitas literer pengarang yang diharapkan dapat memancing pembacaan mendalam atas teks dan memperkaya horison harapan pembaca dalam melakukan serangkaian pembacaan sastra.

\section{Metode Penelitian}

Penelitian ini menggunakan metode content analysis yang diawali dengan pembacaan sastra, heuristik dan hermeneutik, dan memanfaatkan pendekatan intertekstualitas. Melalui metode ini peneliti menentukan dan mengembangkan fokus tertentu, yaitu "Migrasi Simbolik atas Suara Perempuan tentang Kuasa Tubuh" dalam novel Ode untuk Leopold Von Sacher-Masoch karya Dinar Rahayu. Metode content analysis pada prinsipnya menitikberatkan pada objektivitas dan realitas, melakukan klasifikasi pada teks agar dapat mengidentifikasi unsur-unsur di dalam teks secara substansial dengan menggunakan data dan teori yang ada (Haralambos \& Holborn 2000:1020).

Langkah-langkah yang dilakukan dalam penelitian ini yaitu, (1) menentukan teks yang dipakai sebagai objek penelitian, yaitu teks novel Ode untuk Leopold Von Sacher-Masoch karya Dinar Rahayu; (2) melakukan dua tahap pembacaan sastra, heuristik dan hermeneutik pada seluruh populasi penelitian; (3) menganalisis objek penelitian dengan tahap-tahap antara lain, (a) mengidentifikasi migrasi simbolik sebagai jejak-kuasa tubuh dalam teks; (b) menyalin keseluruhan tuturan dari teks sebagai semacam penanda; (c) mengaitkannya dengan 'teks' yang diacu atau yang dihadirkan; (d) mensejajarkan dan membandingkan dengan wacana-wacana atau realitas di luar teks (konstrukkonstruk kuasa tubuh dan perilaku seksualitas), termasuk hasil wawancara pengarang, sebagai upaya intertekstualitas; (e) hasil yang didapatkan tidak sekedar perbandingan, tetapi juga pemikiran di balik wacana tersebut yang ditekankan pada fungsi sosial teks yang menyuguhkan reposisi subjek-objek tubuh.

\section{Hasil dan Pembahasan}

Novel Ode untuk Leopold von Sacher-Masoch karya Dinar Rahayu menceritakan tentang seorang lelaki yang bernama Jonggi dan seorang transeksual bernama Dinar. Semasa kecil, Jonggi pernah melihat penyimpangan seks abangnya dengan ajudannya, dan pernah menjadi korban sodomi abangnya. Saat mengikuti tugas ayahnya ke Klaskow, ia juga pernah diperkosa lima "tante-tante". Selain itu ia juga pernah menyerahkan tubuh pada ibu kandungnya yang kesepian, hingga ibunya hamil. Semasa kuliah, Jonggi pernah menjadi seorang penari striptis di sebuah klub. Di sini ia mulai mengenal perilaku seks masokisme bersama beberapa klien, di antaranya Kartika.

Masa lalu Jonggi mempengaruhi pilihan perilaku seksnya di kemudian hari, sadomasokisme. Setelah menjadi pengusaha, ia bertemu dengan Dinar, seorang transeksual, yang melakukan kontrak selama tiga hari untuk melakukan perbudakan cinta, satu bentuk sadomasokisme. Dinar, adalah seorang transeksual yang berdelusi pernah menjadi perempuan di era mitologi. Karena selalu mengalami 
delusi, ia akhirnya mengoperasi kelaminnya dan memilih menjadi perempuan. Dalam delusinya, Dinar merasa pernah menjadi salah seorang Valkriye yang telah menyerahkan keperawanannya kepada Apollo, dan dalam delusinya itu Jonggi adalah Apollo.

Cerita yang berbalut dunia nyata dan tidak nyata ini dihadirkan melalui wacana yang sangat tidak beraturan. Dalam satu bagian cerita, seringkali berlatar bolak-balik antara dunia nyata dan tidak nyata, tanpa adanya satu penanda apa pun. Bercampurnya teknik penceritaan membuat pembaca harus membaca teks dengan ekstra hati-hati. Terkadang penulis membawa pembaca mulai dari cerita nyata lalu tiba-tiba masuk ke dalam cerita mitologi. Model tersebut merupakan bentuk dari foreshadowing ataupun flashback yang menampilkan bentuk cerita mitologi Yunani dan Skandinavia.

\section{Migrasi simbolik tentang kuasa tubuh}

Maraknya penulisan dan perayaan tubuh perempuan oleh para perempuan pengarang Indonesia mutakhir melahirkan tanggapan pro-kontra yang tiada henti, di antaranya menilai karya tersebut dari kacamata moralitas dan mengabaikan kreativitas literer pengarang. Masing-masing pengarang mempunyai politik tersendiri dalam pengembangan kreativitasnya. Dinar Rahayu, pengarang Ode untuk Leopold Von Sacher-Masoch, dalam mengusung wacana kuasa tubuh memanfaatkan beberapa pengetahuan dan pembacaannya atas teks-teks mitologi Yunani dan Skandinavia serta pembacaannya atas Leopold Von Sacher-Masoch (kehidupan dan karyanya) sebagai "ruh" yang ditransformasikan dalam novelnya. Wacana kuasa tubuh yang ada dalam teks-teks tersebut menjadi suatu "migrasi simbolik" dalam teks yang merangsang pembaca melakukan "pembacaan mendalam" atas teks. Migrasi simbolik dalam tulisan ini dimaksudkan sebagai perpindahan atau pergantian simbol-simbol yang ada dalam teks lain yang dipakai untuk menyimbolkan sesuatu yang serupa atau berkaitan, sehingga untuk memahaminya diperlukan pembacaan mendalam akan teks lain yang menjadi "ruh"nya. Oleh karena itu, pembacaan atas Ode untuk Leopold Von Sacher-Masoch menuntut adanya serangkaian pengalaman pembacaan atas teks-teks yang menjadi horison harapan pengarang. Dengan demikian, tidak akan sampai pada penilaian bahwa wacana kuasa tubuh dalam teks Ode untuk Leopold Von Sacher-Masoch sekedar eksploitasi seksual pengarang yang tak bermoral.

Ditinjau dari judulnya saja, novel Ode untuk Leopold Von Sacher Masoch telah memanfaatkan beberapa migrasi simbolik yaitu migrasi akan kata "Ode" sebagai simbolik dari puisi lirik atau syair pujian untuk seseorang atau sesuatu yang menjadi inspirasi (Gosse 1911:1-2). Dalam Encyclopcedia Britannica disebutkan bahwa ode klasik biasanya tersusun dalam tiga bagian utama, semacam bait berbingkai yang terdiri dari, bait (bergerak ke kanan ke kiri atau ke timur ke barat), antistrope (bergerak ke kiri ke kanan atau ke barat ke timur) dan epode (menyelesaikan gerakan). Selain itu 90\% dari teks-teksnya memiliki refrein, ditemukan beberapa perulangan sajak (Gosse 1911:1-2). Kata "Ode" dalam novel muncul menjadi berbagai teks sebagai varian-varian yang semuanya mengacu akan pemaknaan atas kata tersebut. Migrasi simbolik dari pengertian Ode muncul sebagai perwujudan teks novel Ode untuk Leopold Von Sacher Masoch yang pemaparan ceritanya juga menyerupai cerita berbingkai, antara kekinian dan masa lalu (mitologi) yang bercampur dan seolah-olah dipertemukan dalam delusi tokoh. Dalam teks novel, senantiasa ditemukan konsep keragu-raguan akan "kiri dan kanan" atau "barat dan timur" baik secara eksplisit (misal, pada halaman 107-108) maupun implisit. Selain itu juga ditemukan kisah-kisah yang senantiasa berulang.

Kata "Leopold Von Sacher-Masoch" sebagai simbolitas dari seseorang yang menjadi inspirasi, khususnya mengenai karya-karyanya yang menginspirasi lahirnya novel ini. Oleh karena itu beberapa bagian dari novel ini mengacu pada teks-teks karya Leopold Von Sacher-Masoch. "Ode" atau pujian untuk Leopold tersebut dihadirkan melalui mozaik-mozaik tentang wacana-wacana ataupun pendapat-pendapat Leopold von Sacher-Masoch yang tersebar hampir di seluruh cerita, dengan menampilkan adegan penyimpangan perilaku masokhisme yang melukiskan obsesi dan perbudakan cinta, dunia kemewahan, fantasi, cemeti, dan perjanjian. Wacana tersebut seringkali dimunculkan dalam karya-karya Leopold von Sacher-Masoch, termasuk dalam novel Venus In Furs. Wacana transeksual dan sadomasokisme inilah yang dimanfaatkan dan dicoba untuk ditawarkan secara 
tekstual oleh pengarang dengan cara yang sederhana, wajar, dan alamiah sebagai upaya untuk memobilisasi hal-hal tersebut sebagai bagian dari pengetahuan akan seksualitas dan kuasa tubuh, sebagai sebuah pemaparan bahwa aspek-aspek tersebut merupakan realitas yang memungkinkan ada di bumi ini, termasuk Indonesia (yang berbudaya Timur). Dengan demikian, teks yang ditampilkan hendaknya jangan selalu dicurigai sebagai teks tak bermoral yang sekedar mengumbar eksploitasi seksual dalam teks yang sia-sia belaka.

\section{"Ode": beberapa migrasi simbolik atas suara-suara}

Kata "Ode" muncul dalam teks menjadi beberapa varian yang merepresentasikan hal yang mengindikasikan akan nyanyian, baik secara implisit maupun eksplisit. Varian pertama muncul pada pencantuman beberapa kutipan syair lirik lagu Carmina Burana karya Carl Orff. Kata Carmina Burana diambil dari bahasa Latin yang artinya ode atau nyanyian pujian. Lirik Carmina Burana merupakan perpaduan dari bahasa Latin, Perancis Kuno, Jerman Kuno yang bercerita tentang cinta dan minuman keras (Wikipedia). Dengan demikian kata "ode" dari judul Ode untuk leopold Von Sacher-Masoch dihadirkan melalui pencantuman kutipan teks Carmina Burana (yang artinya juga "ode" atau nyanyian) pada beberapa bagian novel yang di antaranya juga menceritakan tentang cinta dan minuman keras.

Campbell (2002:228) menyebutkan bahwa Carll Orff adalah seorang adalah seorang komponis elemental namun progresif yang menggubah Carmina Burana dan mengembangkan sebuah sistem, disebut sebagai Orff Schulwerk, untuk mengintergrasikan yang alami ke dalam dunia pendengaran dan yang bergerak dan ekspresif. Sehubungan dengan hal ini, dalam cerita penghadiran (pemutaran) Carmina Burana selalu mengiringi sebuah gerakan tertentu (gerakan persetubuhan, dan gerakan penari streapteast). Dalam salah satu bagian lima novel Ode untuk leopold Von Sacher-Masoch (tepatnya pada halaman 63) disebutkan bahwa Carmina Burana diputar untuk mengiringi gerakan Jonggi sebagai penari striptis.

Dalam Ode untuk leopold Von Sacher-Masoch kutipan syair Carmina Burana dari Carl Orff secara eksplisit dihadirkan pada awal wacana bagian 1, 2, 6, 8, dan 9. Urut-urutan bagian tersebut jika dijumlah semua akan kembali ke angka 9, yaitu: angka 9; $8+1=9 ; \quad(2+6)+1=9$. Angka 9 merupakan simbolisasi dari pembagian narasi novel yang terbagi menjadi sembilan bagian, hal ini merupakan migrasi simbolik dari sembilan muse (kata "musik" berasal dari bahasa Yunani Muse). Selain itu angka 9 juga muncul dalam teks sebagai "für Elise" atau Simfoni Kesembilan Beethoven yang dimainkan oleh Renata (Kak Jonggi). Dalam salah satu ensiklopedi tentang musik disebutkan bahwa simfoni ini tercipta dari rasa sepi akibat tekanan psikologis yang mendalam hingga tercipta karya yang fenomenal. Penghadiran kata "Simfoni Kesembilan" ini merupakan sebuah migrasi simbolik yang memerlukan pembacaan mendalam.

Salah satu latar yang dihadirkan dalam Ode Untuk Leopold Von Sacher-Masoch adalah tentang mitologi Yunani, demikian pula beberapa nama tokoh juga memanfaatkan tokoh-tokoh dalam mitologi Yunani. Dalam mitologi Yunani, Dewa Apollo dikenal sebagai Dewa Pengobatan sekaligus Dewa Musik (Campbell 2002:349). Apollo merupakan salah satu tokoh dalam mitologi Yunani yang juga dihadirkan sebagai tokoh dalam novel Ode Untuk Leopold Von Sacher-Masoch melalui delusi Dinar. Musik (yang berkaitan dengan nyanyian) berasal dari kata Yunani "muse". Dalam mitologi Yunani, dikenal bahwa sembilan muse (dewi-dewi bersaudara yang menguasai nyanyian, puisi, kesenian, dan ilmu pengetahuan) merupakan anak Zeus, raja para Dewa, dengan Mnemosyne, Dewi Ingatan (Campbell 2002:36). Delusi dari Dinar yang mengungkapkan tentang mitologi Yunani, merupakan representasi dari ingatan, atau lebih tepatnya migrasi simbolik dari Dewi Mnemosyne (Dewi Ingatan).

"Ode" atau nyanyian atau perayaan dalam novel Ode Untuk Leopold Von Sacher-Masoch adalah "suara-suara" dari perempuan pengarang akan esensi tubuh. Suara-suara yang hendak dimobilisasi adalah wacana akan kuasa tubuh mengenai ketidakpentingan status gender (perempuan atau laki-laki) 
melalui fenomena transeksual yang dihadirkan melalui tokoh Dinar dan juga Artemis dalam mitologi Yunani; fenomena incest yang dihadirkan melalui kisah persetubuhan Ouranous dan Gea (ibu Ouranous) yang mengawali rangkaian narasi yang mengemukakan persetubuhan Jonggi dan Ibu kandungnya (Ny. Dicky Kalangi); serta wacana sadomasokisme yang dihadirkan melalui tokoh Jonggi-Dinar; Jonggi-Para perempuan di rumah Konsul Jendral di Karakow dan Valhalla; JonggiKartika dan Dinar (Valkyrie)-Apollo juga penghadiran beberapa nama pasangan sadomasokis Leopold Von Sacher-Masoch beserta kontrak-kontrak seksual sebagaimana kontrak seksual Jonggi dan Dinar selama tiga hari, atau Kartika-Jonggi, sebagai budak-majikan, guru-murid, dalam rangka pencapaian kepuasan.

Setiap fenomena yang dihadirkan dalam inti cerita senantiasa diawali atau dibayangi oleh hadirnya fenomena yang sama dalam cerita bayangan (mitologi) yang dikemas sebagai delusi tokoh, dan mengandung "suara-suara" tersembunyi, seperti kisah penyebab di balik perilaku yang demikian. Hadirnya mitologi yang mengemukakan fenomena yang sama dimaksudkan sebagai legitimasi akan fenomena tersebut sebagai suatu kewajaran yang senantiasa "mungkin" untuk hadir di dunia ini, tetapi hadirnya fenomena tersebut dalam cerita inti senantiasa diawali oleh adanya "masa lalu" sebagai penyebabnya. Dengan demikian, hal ini merupakan pesan implisit yang disampaikan pengarang, bahwa bentuk perilaku seksual memang merupakan sesuatu yang "wajar" dan "mungkin" terjadi dalam kehidupan dan tidak perlu dianggap sebagai sesuatu yang "menyimpang" karena setiap orang memungkinkan untuk menjadi demikian, namun perilaku tersebut sebenarnya hadir karena peristiwa "masa lalu" yang traumatik. Seseorang menjadi transeksual atau sadomasokis sebenarnya bukan karena takdir tetapi karena beberapa sebab yang sebenarnya bisa dihindari atau dijaga sebelum hal tersebut terjadi.

\section{Kuasa tubuh dan suara-suara "Leopold Von Sacher Masoch"}

Salah satu migrasi simbolik tentang kuasa tubuh yang mengacu pada sosok Leopold dalam teks Ode Untuk Leopold von Sacher-Masoch adalah ditemukannya jejak-jejak sadomasokisme dalam teks, yaitu adanya kekerasan dan perjanjian (kontrak) seksual dalam setiap relasi persetubuhan. Suara-suara Leopold Von Sacher Masoch hadir melalui penyebutan nama-nama tokoh yang digunakan dalam karya-karya Leopold, seperti Wanda, Leopold, dan tokoh Fanny Pistor alias Baroness Bogdanoff beserta kontrak seksual mereka. Jejak-jejak tersebut, antara lain hadir dalam deskripsi akan perilaku sadisme. Dinar selalu melakukan perilaku sadisme yang diinginkan oleh Jonggi.

Bila ia separo masokis dan bahagia dengan itu biarlah. Kalau peran Leopold von Sacher Masoch dan isterinya, Wanda, ingin ia mainkan denganku, kulakukan tanpa terpaksa, tidak seperti Wanda yang melakukannya karena ia bergantung secara financial pada Masoch... Ia begitu tergerak dalam keadaan seperti itu, dan itu akan kulakukan bila membuatnya senang. Kalau ia ingin diikat seperti anjing dan dicambuk di bawah kakiku seperti Masoch memimpikan diikat dan dicambuk oleh seorang perempuan berpakaian bulu, aku akan mengabulkan keinginannya. Kalau ia ingin kumaki dan kuhina, akan kusebutkan semua makian yang paling kotor dan paling menyakitkan hati. Kalau ia ingin aku jadi bidadari yang diusir dari langit dan menjadi setan betina yang menyetubuhi dan merampas spermanya, akan kukerjakan (Rahayu 2002:139-140).

Kutipan di atas menggambarkan bahwa Dinar sebenarnya bukanlah pengidap sadisme. Semua perilaku sadisme yang dia lakukan terhadap Jonggi hanyalah untuk memuaskan gairah seksual masokisme Jonggi dan hal tersebut dilakukan tanpa adanya paksaan. Dinar mengibaratkan perlakuan sadisme yang dilakukannya tidak sama seperti yang dilakukan oleh Wanda dan Leopold Von Socher Masoch. Hubungan sadisme Wanda dan Masoch dilakukan dengan terpaksa karena ketergantungan finansial Wanda terhadap Masoch.

Dinar mengucapkan kalimat yang menunjukkan suatu pernyataan kesediaan untuk memenuhi semua fantasi Jonggi. Oleh karena kesediaannya, Dinar mewujudkan semua fantasi Jonggi bahkan apabila 
Jonggi ingin diperlakukan seperti yang diimpikan oleh Masoch maka ia akan melakukannya. Sebagai seorang masokisme, fantasi yang terwujud merupakan hadiah yang sangat berharga dan itu membuat Jonggi merasakan kesenangan dan kenikmatan yang tidak terkira atas semua rasa sakit yang ia terima.

Berbeda dengan Kartika yang pada dasarnya memang telah mengidap sadisme dikarenakan suatu trauma. Sadisme yang dilakukan oleh Kartika memang untuk membangkitkan gairah seksualnya. Perilaku sadisme Kartika tergambar ketika ia datang ke sebuah klub malam, dengan tujuan untuk memuaskan fantasinya sebagai pengidap perilaku sadisme. Perilaku tersebut dilampiaskan kepada Jonggi seorang penari striptease yang bisa diperlakukan dengan sesuka hatinya. Kartika mengibaratkan seorang laki-laki hanyalah sebagai "hidangan". Hal tersebut dapat dilihat pada kutipan berikut.

\begin{abstract}
Baginya, laki-laki itu hidangan. Dari dapur ia telah menyiapkan kuah kental untuk disiramkan ke atas daging, hangat, gurih. Ia menyuruh laki-laki itu membuka mulut, meletakkan garnis dari tomat yang berbentuk angsa di antara gigi-giginya. Menaruh daun selada di antara sudut dan celahnya, juga irisan bundar bawang besar, irisan indah wortel bergerigi, dan ia menyiramkannya perlahan ke kepala dan rambut dan permukaan tubuh itu. Sampai habis seluruh cairan kental kuah itu. Lumurannya menetes-netes ke atas seprai. Lengket dan harum. Mulutnya menimbulkan suara berdecak. Suara kaki berketipuk di lantai terdengar. Kartika menepukkan tangan di atas tempat tidur. Dengan mata coklatnya, Ogami, anjing Doberman Pinscher yang kedua kupingnya masih dibalut perban setelah dipangkas supaya tidak terlalu caplang, memperhatikan majikannya. Ia segera meloncat mengikuti perintah, menjilati tubuh yang terbaring telanjang dengan perut dan hamper semua bagian tubuhnya terlumuri kuah. Kartika menarik kursi, duduk dan memperhatikannya (Rahayu 2002:147-148).
\end{abstract}

Kutipan di atas mendeskripsikan bahwa Kartika berperilaku sadisme. Perilaku tersebut dilakukan Kartika terhadap Jonggi. Kartika melakukan perilaku sadisme menyebabkan rasa sakit fisik maupun psikologis pada Jonggi yang dilakukan dengan sengaja bertujuan untuk memperoleh kepuasan seksual, pemuas fantasinya dan membangkitkan gairah seksual. Perilaku sadisme Kartika disebabkan oleh trauma dan kecemasan yang dialami pada masa kakak-kanak. Karena akar pertumbuhan terbentuknya perilaku seksual terjadi pada masa kanak-kanak, sehingga aspek munculnya penyimpangan seksualitas tidak lain bermula pada aspek seksualitas pada masa kanak-kanak. Seseorang yang memiliki trauma yang berkepanjangan memiliki kecenderungan berperilaku seks menyimpang. Hal tersebut terlihat pada tokoh Kartika yang memiliki berbagai kejadian kekerasan yang dialaminya ketika masa kanak-kanak. Kejadian tersebut adalah tindakan kekerasan yang dilakukan oleh ayahnya terhadap dirinya dan ibunya. Meskipun kejadian itu terjadi pada masa kanakkanak tetapi Kartika tidak bisa dengan mudah melupakannya.

Migrasi simbolik tentang kuasa tubuh yang mengacu pada sosok Leopold kembali muncul dalam teks saat mendeskripsikan relasi tubuh Jonggi dan Kartika sebagai berikut. "Baginya, Kartika adalah segalanya. Ia adalah Fanny Pistor alias Baroness Bogdanoff yang menandatangani kontrak dengan Sacher-Masoch untuk memperbudaknya" (Rahayu 2002:145). Fanny Pistor alias Baroness Bogdanoff dan Wanda adalah tokoh-tokoh simbolik yang digunakan untuk menggambarkan sadomasokisme Leopold. Dalam novel ini tokoh-tokoh tersebut kemudian bermigrasi menjadi Dinar dan Kartika dalam hubungannya dengan sadomasokisme Jonggi. Selain dipersandingkan dengan Fanny Pistor alias Baroness Bogdanoff (tokoh dalam Venus In Furs karya Leopold), sikap sadis Kartika juga dipersandingkan dengan Artemis, salah satu tokoh mitologi Yunani, saudara Apollo yang juga berperilaku sadis. Hadirnya tokoh-tokoh yang dipersandingkan dengan Kartika tersebut berfungsi untuk meligitimasi bahwa sadomasokisme merupakan salah satu pilihan seksual yang sudah ada sejak jaman dahulu.

Kuasa tubuh dalam Ode untuk Leopold Von Sacher-Masoch diwacanakan melalui kekerasan dalam perbudakan, yaitu melalui hubungan kekuasaan budak dan majikan dalam realitas kehidupan, maupun perbudakan cinta dalam perilaku seksual sadomasokisme. Kuasa tubuh ini dinarasikan melalui cerita dalam dunia nyata melalui relasi tokoh Jonggi-Dinar (transeksual dan sadomasokisme) dalam dunia 
nyata, yang merupakan migrasi simbolik dari relasi tokoh Apollo-Dinar dalam dunia mitologi; JonggiKartika (sadomasokisme); Jonggi-Ibu Jonggi (incest) dalam dunia nyata, yang merupakan migrasi simbolik dari Ouranous-Gea (incest) dalam mitologi Yunani, serta melalui delusi Dinar dalam cerita mitologi Yunani dan Skandinavia, yang menghadirkan kisah Dinar-Apollo (majikan-budak, sadomasokis).

Dalam Ode untuk Leopold Von Sacher-Masoch tubuh seseorang (baik laki-laki mupun perempuan) dapat dikuasai oleh orang lain yang bermateri (memiliki uang) yang bisa membeli dirinya. Kartika yang bermateri dapat membeli Jonggi, demikian pula Dokter Cundoko dengan uangnya ia dapat membeli tubuh Jonggi untuk diperjualbelikan pada Kartika sekaligus merekam persetubuhan Kartika dan Jonggi dan menghadiahkannya pada Ny. Cundoko. Dengan uangnya Kartika dapat memperlakukan Jonggi sebagaimana layaknya budak atau hidangan. Hal yang sama juga berulang, saat Jonggi Kalangi, telah kaya dan dapat membeli Dinar yang sebetulnya seorang transeksual. Dengan uangnya Jonggi Kalangi dapat melakukan transaksi sadomasokisme dengan Dinar, sebagaimana ia dulu dibeli oleh Kartika.

\section{Migrasi simbolik atas ruang dan waktu}

Novel Ode untuk Leopold von Sacher-Masoch menyajikan dua dunia, yaitu dunia nyata dan dunia tidak nyata. Dunia nyata merupakan cerita inti, sedangkan dunia tidak nyata diwujudkan melalui delusi tokoh Dinar yang merepresentasikan dunia mitologi, yaitu mitologi Yunani dan Skandinavia. Sehubungan dengan adanya dua jenis struktur ruang yang dihadirkan maka dihadirkan pula dua struktur dimensi waktu, dimensi waktu kekinian dan dimensi waktu masa lalu (mitologi). Penghadiran ruang dan waktu yang dimunculkan saling tumpang tindih, tidak berbatas yang jelas, dan lebih mengesankan kechaosan. Dalam satu sekuen seringkali dihadirkan struktur ruang dan waktu yang berbeda, dan terkesan tumpang tindih. Kekacauan yang dihadirkan tersebut merupakan representasi dari suatu migrasi simbolik dari nama dewa tertinggi dalam mitologi Yunani, Chaos.

Penghadiran migrasi simbolik atas ruang dan waktu yang kadangkala tumpang tindih antara dunia nyata dan dunia mitos, dan antara kekinian dan masa lalu, merupakan pelegitimasian atas fenomena atau perilaku tersebut. Hal ini sebagaimana kutipan berikut.

...Ia adalah Fanny Pistor alias Baroness Bogdanoff yang menandatangani kontrak dengan Sacher-Masoch untuk memperbudaknya. ...Kartika bisa mengikatnya tertelungkup dan menyepakkan makanan dengan sepatu bertumit tinggi ke dekat mulutnya dan menyuruh memakannya, atau menjilati sepatu itu. Ia adalah kaisar perempuan yang punya otoritas penuh atas tubuh dan jiwanya. Ia punya kualitas Penguin Kaisar betina di Kutub Selatan, Aptenodytes forsteri, ... Ia adalah Artemis yang menyuruh anjing mencabik orang yang mengintipnya mandi. Agung. Omnipoten. ... (Rahayu, 2002:146).

Tokoh Fanny Pistor alias Baroness Bogdanoff, Kartika, dan Artemis adalah tokoh-tokoh yang hidup di ruang dan waktu yang berbeda. Ketiga tokoh tersebut sama-sama digunakan untuk merepresentasikan kuasa tubuh perempuan atas laki-laki, perempuan "agung" yang menguasai lakilaki karena kemampuan materinya.

Begitu pula dengan incest yang dilakukan antara ibu dan anak, Gea dan Ouranous, dalam mitologi Yunani yang dihadirkan pada awal bagian 7 novel Ode untuk Leopold Von Sacher-Masooch (halaman 101) untuk membuka narasi bagian yang menceritakan kisah incest antara Nyonya Dicky Kalangi dan putranya Jonggi Kalangi (halaman 111-113). Migrasi simbolik atas ruang dan waktu ini melegitimasi bahwa incest merupakan sebentuk kegiatan seksual yang telah terjadi sejak jaman lampau, sehingga terjadinya incest bukan karena pengaruh pergaulan bebas.

Migrasi simbolik atas ruang dan waktu juga direpresentasikan melalui pemanfaatan latar "Valhalla". Dalam novel Ode untuk Leopold Von Sacher-Masooch terdapat dua tempat berbeda dengan nama yang sama, yaitu Valhalla. Dua Valhalla tersebut adalah Valhalla dalam mitologi Skandinavia dan 
Valhalla sebagai nama klub tempat di mana Dinar bekerja. Dalam mitologi Skandinavia, Valhalla adalah suatu tempat berkumpulnya para prajurit Odin. Setiap hari Valhalla selalu penuh dengan prajurit Odin. Mereka melepas kepenatan di tempat tersebut setelah seharian melakukan latihan peperangan. Di dalam Valhalla para prajurit dilayani oleh para Valkyrie, dan Dinar dalam delusinya merasa dirinya adalah salah seorang Valkyrie yang menyerahkan keperawanannya pada Apollo agar ia bisa mortal dan terlahir kembali sebagai laki-laki. Namun, dalam sejarah mitologi Skandinavia tidak ada seorang Valkyrie pun yang bernama Dinar atau yang menyerupai nama tersebut, dan salah satu anak Loki bernama Nari, bukan Dinar. Dalam dunia nyata, Valhalla merupakan nama sebuah klub yang menyuguhkan berbagai macam pertunjukkan tanpa ada batasan. Dalam klub tersebut semua orang bebas melakukan apa saja asal semua orang senang, dan tidak ada paksaan. Dalam teks dikisahkan bahwa Dinar bekerja di Valhalla. Valhalla dalam hal ini mengindikasikan satu klub sadomasokis yang seringkali didatangi oleh tante-tante girang yang merasa kesepian.

Migrasi simbolik atas ruang dan waktu juga direpresentasikan melalui pemanfaatan latar "Valhalla" dalam hal ini untuk merepresentasikan suatu tempat yang memiliki kesamaan fungsi yaitu sebagai tempat untuk berkumpulnya orang-orang untuk memperoleh kesenangan tanpa adanya batasan. Selain itu, masih banyak ditemukan beberapa contoh migrasi simbolik atas ruang dan waktu yang bukan merupakan sesuatu yang sia-sia hadirnya.

\section{Simpulan}

Pembacaan mendalam melalui beberapa migrasi simbolik atas suara perempuan tentang kuasa tubuh dalam Ode untuk Leopold Von Sacher-Masoch memperlihatkan bahwa perempuan pengarang dalam menuliskan tubuhnya tidak semata-mata menghasilkan sebuah tulisan yang semata-mata mengeksplotasi seksualitas, namun justru merupakan upaya untuk menyuarakan aspirasi perempuan akan berbagai hal yang menyangkut "kuasa tubuh". Upaya ini berupa migrasi simbolik yang dikaitkan dengan ruh teks lain, yaitu beberapa pembacaan atas mitologi ataupun kisah-kisah yang menginspirasi, dalam hal ini mitologi Yunani dan mitologi Skandinavia serta karya-karya Leopold Von Sacher Masoch, khususnya Venus in Furs.

Melalui beberapa migrasi simbolik yang dipakai dalam Ode Untuk Leopold Von Sacher Masoch, Dinar, sebagai perempuan pengarang mengajak pembaca bermigrasi dari totalitas menuju multiplisitas. Kita terbiasa hidup dalam kesulitan, kesatuan, ketunggalan, penyeragaman, sehingga gamang menghadapi realitas kelianan (otherness), perbedaan, dan diversitas. Kita terbiasa merangkai makna tunggal, dan tidak terbuka terhadap makna jamak (polysemy). Kita terbiasa dengan keterpusatan dan sentralisasi dan cemas menghadapi ketakberpusatan dan desentralisasi. Kita terbiasa dengan totalitas dan canggung terhadap multiplisitas. Kita terbiasa dengan ketunggalan (ideologi, identitas, standardetika), dan asing terhadap 'keserbaragaman' (multiplicity).

Setiap tubuh mempunyai hasrat menjadi 'pusat' (center): pusat kekuasaan, pusat kebenaran, pusat pengetahuan, pusat perhatian (popularitas), pusat kekayaan (monopoli) dan pusat kekuatan. Tubuh seringkali merasa menjadi bagian dari pusat, mengiidentifikasi diri sebagai pusat, bahkan menjadi pusat itu sendiri. Tubuh enggan menjadi 'pinggiran', menjadi sang (the others). Tubuh dikuasi ego dan tidak pernah mau berbagi (sharing). Tubuh seringkali berkecenderungan melihat sang lian: orang lain, suku lain, kelompok lain, gender lain, ras lain, agama lain sebagai 'sang pinggiran' (the peripiieral other), yang harus memusat pada kita.

Ode Untuk Leopolod Von Sacher Masoch menggambarkan reallitas akan adanya ketidakadilan dan dekadensi. Dalam seksualitas ada permainan kuasa; setiap tubuh dapat membiarkan diri terseret, atau menolak dan bersikap. Yang menolak maupun yang bersikap sama-sama membuat pilihan-pilihan yang akan berhadapan dengan institusi dan norma-norma. Dinar Rahayu, sebagai perempuan pengarang, menyajikan beberapa pilihan perilaku seksualitas dan menyerahkan sepenuhnya pada pembaca untuk memberikan penilaian dan melakukan pilihan, dengan menghadirkan sejumlah "tenaga lain" atau "ruh" lain dalam teks tersebut. 
Migrasi simbolik yang menghadirkan ruh teks lain merupakan suatu upaya pengembangan imajinasi dan kreativitas literer yang merangsang pembacaan mendalam atas teks. Akhirnya, melalui migrasi simbolik, perpindahan dan peralihan aktivitas-aktivitas sosial, ekonomi, politik kebudayaan, seksualitas, bahkan spiritualitas ke dalam teks (dalam hal ini karya sastra), dapat ditransformasi dan dimaknai secara lebih luas dan lebih mendalam dengan mendialektikakan fenomena tersebut dalam pandangan masa lalu dan mendatang dan memperkaya horison harapan dalam pembacaan.

\section{Daftar Pustaka}

Campbell D (2002) Efek mozart. Jakarta:Gramedia Pustaka Utama.

Cixous H (1981) The laugh of Medusa, dalam E. Marks dan I de Courtrivon (ed.), New french feminisms, Sussex: Harvester Press.

Foucault M (1980) Power/ knowledge: wacana kuasa/ pengetahuan. Yogyakarta: Bentang.

Foucault M (1987) The order of discourse. Dalam Young R (ed). Untying the Text: A PostStructuralist Reader. London and New York: Routledge and Kegan Paul.

Foucault M (1990) The history of sexuality. London: Penguin Books.

Foucault M (2003) (reprinted). The archaelogy of knowledge. London and New York: Routledge.

Gosse E (1911) "Ode" dalam The Encyclopaedia Britanica Volume XX (11 ${ }^{\text {th }}$.ed). New York: The Encyclopædia Britanica Company. New York: Perusahaan Encyclopædia Britanica. pp. 1-2. hal. 1-2.

Haralambos \& Holborn (2000) Sociology themes and perspectives. Fifth Edition. London: Collins Education.

Prihatmi R (1986) Pengarang-pengarang wanita Indonesia: Seulas Pembicaraan. Jakarta: Pustaka Jaya.

Rahayu D (2005) Ode untuk Leopold Von Sacher-Masoch. Jakarta: Pustaka Jaya.

Sacher-Masoch LV (2006) Venus in furs. London: Penguin Books.

Sumardjo J (1982) Novel populer Indonesia. Yogyakarta: Nur Cahaya.

Sontag S (1969) The pornographic imagination. Dalam Styles of Radical Will. New York:

Dell Publishing.

Wikipedia (2013) (www.wikipedia.org/wiki/Carmina_Burana_(Orff). 